IZA DP No. 5938

Does It Pay to Be Productive?

The Case of Age Groups

Alessandra Cataldi

Stephan Kampelmann

François Rycx

August 2011

Forschungsinstitut

zur Zukunft der Arbeit

Institute for the Study

of Labor 


\title{
Does It Pay to Be Productive? The Case of Age Groups
}

\author{
Alessandra Cataldi \\ Università di Roma "La Sapienza" and SBS-EM (DULBEA) \\ Stephan Kampelmann \\ Université de Lille, CLERSE and SBS-EM (DULBEA) \\ François Rycx \\ Université Libre de Bruxelles, SBS-EM (CEB, DULBEA) \\ and IZA
}
Discussion Paper No. 5938
August 2011

\author{
IZA \\ P.O. Box 7240 \\ 53072 Bonn \\ Germany \\ Phone: +49-228-3894-0 \\ Fax: +49-228-3894-180 \\ E-mail: iza@iza.org
}

\begin{abstract}
Any opinions expressed here are those of the author(s) and not those of IZA. Research published in this series may include views on policy, but the institute itself takes no institutional policy positions.

The Institute for the Study of Labor (IZA) in Bonn is a local and virtual international research center and a place of communication between science, politics and business. IZA is an independent nonprofit organization supported by Deutsche Post Foundation. The center is associated with the University of Bonn and offers a stimulating research environment through its international network, workshops and conferences, data service, project support, research visits and doctoral program. IZA engages in (i) original and internationally competitive research in all fields of labor economics, (ii) development of policy concepts, and (iii) dissemination of research results and concepts to the interested public.
\end{abstract}

IZA Discussion Papers often represent preliminary work and are circulated to encourage discussion. Citation of such a paper should account for its provisional character. A revised version may be available directly from the author. 
IZA Discussion Paper No. 5938

August 2011

\section{ABSTRACT \\ Does It Pay to Be Productive? The Case of Age Groups ${ }^{*}$}

Using longitudinal matched employer-employee data for the period 1999-2006, we investigate the relationship between age, wage and productivity in the Belgian private sector. More precisely, we examine how changes in the proportions of young (16-29 years), middleaged (30-49 years) and older (more than 49 years) workers affect the productivity of firms and test for the presence of productivity-wage gaps. Results (robust to various potential econometric issues, including unobserved firm heterogeneity, endogeneity and state dependence) suggest that workers older than 49 are significantly less productive than prime age and young workers. In contrast, the productivity of middle-age workers is not found to be significantly different compared to young workers. Findings further indicate that average hourly wages within firms increase significantly and monotonically with age. Overall, this leads to the conclusion that young workers are paid below their marginal productivity while older workers appear to be "overpaid" and lends empirical support to theories of deferred compensation over the life-cycle (Lazear, 1979).

JEL Classification: J14, J24, J31

Keywords: $\quad$ wages, productivity, aging, matched panel data

Corresponding author:

François Rycx

SBS-EM (CEB, DULBEA)

Université Libre de Bruxelles

CP 114/02, Avenue F.D. Roosevelt, 50

B-1050 Brussels

Belgium

E-mail: frycx@ulb.ac.be

*We would like to thank Statistics Belgium for giving access to the data. The usual disclaimer applies. 


\section{Introduction}

In European economies, the aging of the population, due to the decrease in birth rates and rising life expectancy, represents a distinctive demographic change that has been documented by international institutions (OECD 2006, European Commission 2007). This evolution is mirrored on the European labour market, where the last thirty years have brought a declining share of young people in the labour force. In many countries the labour market participation of elderly people has increased following raises in the retirement age. These trends are likely to persist in the future: according to projections the employment rate of older workers will increase by 19 p.p. from 40\% in 2004 for the EU25 to 47\% by 2010 and 59\% in 2025 (Economic Policy Committee and European Commission 2006).

Consequently, understanding the potential effects of an aging work force on labour market performance in general and firm productivity in particular might be crucial in order to help fine-tune firms' human resource management, workers' employability and labour market policies (Borsch-Supan 2010).

What is more, the link between age and productivity is connected to another topical issue, namely the relationship between age and earnings. If markets are perfectly competitive, then wages would simply reflect individual productivity. But if this is not the case, other mechanisms of wage determination could also play a role. According to the deferred payment model of Lazear (1979), for example, firms create incentives for younger workers to curb shirking and boost job attachment through remuneration schemes that raise wages with age independently of individual productivity. A better understanding of the age-wage-productivity nexus is therefore relevant for sound economic policy and human resource management alike.

The problem is that compared to wages, measuring productivity and assessing its connection with aging is much more complex given that we often lack a direct measure of productivity differences (Aubert and Crépon 2003). In fact, the link between firm-level productivity and the age structure has not yet been identified satisfactorily: existing research is relatively scarce and controversial, both theoretically and empirically. Indeed, the micro data necessary to study the subject at the firm level has become available only recently.

This paper provides one of the first attempts to evaluate empirically the relationship between age, wage and productivity. More precisely, we examine how changes in the proportions of young (16-29 years), middle-aged (30-49 years) and older (more than 49 years) workers affect the productivity of firms and investigate the presence of productivity- 
wage gaps for these age groups. To do so, we use longitudinal matched employer-employee data covering the Belgian private sector over the period 1999-2006. Our data offers several advantages. First, the panel provides accurate information on average productivity and wages within firms (i.e. on the average value added per hour worked and the mean hourly wage) and allows to control for a wide range of worker and firm characteristics (such as education, occupation, gender, working time, type of contract, firm size, firm age and sector). In particular, the data allows us to compute age variables in terms of hours worked rather than on a per capita basis. Second, we are able to address important measurement issues such as firm-level unobserved heterogeneity, endogeneity of age shares and state dependence of firm productivity and wages. Hence, our data allows us to tackle various potential biases that are not always accounted for in the existing literature.

The structure of the paper is as follows: the next section presents a selective overview on the existing literature; sections 3 and 4, respectively, describe our methodology and data set; the impact of different age groups on firm productivity and the comparison between estimated age-wage and age-productivity profiles is developed in section 5; the final section concludes.

\section{Review of the literature}

In this section we present the strands of the existing literature that are most relevant for the relationship between age, wage and productivity. By and large, it is fair to say that the topic is still open to debate since results are relatively scarce and controversial.

From a theoretical point of view, two diametrically opposed relationships between age and productivity can be envisaged. On the one hand, some approaches suggest that older workers might be less productive than younger ones. Indeed, the decline in cognitive ${ }^{1}$ functioning, mental and physical abilities (Shepard 1999) that has been associated with aging may negatively affect performance. Moreover, since older workers are thought to be less healthy than younger counterparts and suffer more frequently from chronic diseases, they might perform less efficiently, have higher rates of absenteeism and therefore lower productivity (Ng and Feldman 2008). Further, if productivity is an increasing function of investment in new knowledge and a decreasing function of human capital depreciation, at the end of the career there will be a reduction in performance as the positive impact of recently acquired human capital will be outweighed by increasing depreciation of skills (Walewski

\footnotetext{
${ }^{1}$ Cognitive abilities reflect inter alia numerical capabilities and verbal, reasoning and problem-solving abilities.
} 
2008). This could be particularly true in periods of swift technological change in which acquired skills depreciate rapidly: in such a context, elderly people are often seen as being less willing and motivated than younger workers to continuously update their competences due to difficulty in processing speed and learning capabilities (Skirbekk 2003). In addition, to the extent that technological progress is very fast and determines a rapid depreciation of skills, older workers might have an incentive to retire as soon as possible (Bartel and Sichermann 1993). According to empirical research, this appears to be the general perception that employers have of older workers (Itzin et al., 1994). Employers might also be more reluctant to invest in training for older workers due to the shorter period of time to benefit from on-the-job training (Brooke, 2003; Prskawetz et al., 2006). Finally, young people are thought to be more motivated to exert higher effort as they stand to gain relatively more from positive signals sent to their employers (Grund and Westergaard-Nielsen, 2005). Conversely, older workers might invest less effort in terms of hours spent at work or concentration since the scope to benefit from higher performance though promotions and career advancements is relatively smaller compared to employees in early stages of their careers (Tang and MacLeod 2006).

On the other hand, some of the literature focuses on certain implications of the human capital model and stresses the positive impact that elderly people might have on firm productivity (Mincer 1974). This second strand of theories suggests that older workers will perform better than younger ones given that they have accumulated more experience and know-how than younger workers (Czaja and Sharit 1998). There is also a higher probability that they have been assigned to a position in the firm's internal organization that suits their individual skills (Jovanovic 1979) and are more likely to have correctly matched their job preferences with the employer’s requirements (Johnson, 1978). Further, as Skirbekk (2003) points out, in jobs where verbal abilities and experience are more important than cognitive capacities and speediness, elderly workers might be as productive as younger ones, or even more. Finally, technological progress and compulsory training might have a positive effect if they induce aging workers to update their skills, remain in the job market and preserve their productivity (Bartel and Sichermann 1993).

As regards empirical studies, results are mixed and diverging as well. Most papers relying on matched employer-employee data report a positive but hump-shaped relationship between age and firm performance. In general, strong decreases in productivity are observed 
after the age of $50^{2}$. However, Hellerstein and Neumark (1995) and Hellerstein et al. (1999) found that productivity peaks at 55 years or more. In general, studies investigating the ageproductivity relationship use workers' mean age or shares of workers by age groups as an indicator of the age structure of the workforce, while the most common measure of firm productivity is firm's value added. Lallemand and Rycx (2009), using cross section matched employer-employee data for the Belgian economy and using value added per capita to proxy productivity, find that young workers are significantly more productive than older ones. They also assess the difference between ICT and non-ICT sectors and conclude that the effect of age on productivity is much more pronounced in ICT firms. Tang and MacLeod (2006), using panel data to evaluate productivity growth in ten Canadian provinces, find a negative and significant impact of the share of older workers (aged 55 and more) on productivity growth (measured by GDP). By contrast, Bertschek and Meyer (2008) analyse a panel of firm level data for the German manufacturing and service industries, measure productivity by sales per workers and find that older workers (aged 49 and more) are not less productive than prime age workers, while younger workers (aged less than 30) would be less productive than prime age workers. In particular, they find that technological progress, proxied by the use of computer, has a positive impact on older workers productivity. These results are in line with Göbel and Zwick (2009). Using panel data on the German labour market, they show that establishment productivity increases with the share of workers until the age group 50-55 years and decreases only slightly afterwards.

A less analysed but equally unresolved aspect concerns the relationship among age, wage and productivity. As already mentioned, while standard theory predicts that wages will always reflect marginal productivity, other theories claim that wages can be determined by factors independent from productivity. The deferred payment model (Lazear 1979), for instance, predicts that wages will increase with age in order to recompense workers for their loyalty to the firm. More precisely, it suggests the existence of a negative (positive) gap between wage and marginal productivity for young (older) workers.

Testing for productivity-wage gaps, Aubert and Crépon (2003) — on the basis of data covering the French manufacturing, service and commerce sectors and quantifying productivity by value added — find that individual productivity grows until the age of 40 and then stabilizes but report no evidence of a productivity-wage gap for elderly people (except

\footnotetext{
2 See Andersson et al. (2002) for Sweden, Aubert and Crépon (2003) for France, Dostie (2006) for Canada, Grund and Westergaard-Nielsen (2005) for Denmark, Haegeland and Klette (1999) for Norway, Haltiwanger et al. (1999) for US, Hellerstein and Neumark (2004) for US, Malmberg et al. (2005) for Sweden, Prskawetz et al. (2006) for Austria.
} 
above 55 years old). Van Ours and Stoeldraijer (2010) use a matched worker-firm panel from the Dutch manufacturing sector and value added to proxy productivity. Once they take into account the endogeneity of age shares and firm fixed effects, they find that both productivity and wage costs increase with age but cannot find strong evidence for productivity-wage gaps. Ilmakunnas and Maliranta (2005) analyse Finnish manufacturing plant data and specify different productivity equations using value added and sales as proxy for productivity. They find an increasing productivity-wage gap by age that they impute to strong seniority effects in wage setting. A significant wage-productivity gap, but of the opposite sign, is found in Cardoso et al. (2010) on the basis of administrative longitudinal data on workers and their firms in the manufacturing and services private sector in Portugal and measuring productivity with total sales per labour unit. They observe that productivity peaks around the age of 50 and then remains rather constant, whereas wages are quite flat after 29 years old and decline after 50. According to their estimates the contribution of older workers to firm productivity exceeds their wages.

\section{Methodology}

The test developed in this article is based on the simultaneous estimation of a value-added function and a wage equation at the firm-level. The value-added function yields parameter estimates for the average marginal product of each workers' age group, while the wage equation estimates the respective impact of each age category on the average wage paid by the firm. Given that both equations are estimated with the same set of firms, age groups and covariates, the parameters for marginal products and wages can be compared and conclusions on age productivity-wage gaps can be drawn. This technique was pioneered by Hellerstein et al. (1999) and refined by Aubert and Crépon (2003), van Ours (2009), Göbel and Zwick (2009), van Ours and Stoeldraijer (2010) and others.

Equation (1) is a function linking a range of inputs of firm $i$ to its added value $Y_{i}$.

$$
Y_{i}=F\left(K_{i}, Q L_{i}\right)
$$

where $K_{i}$ represents the firm's capital stock and $Q L_{i}$ is a quality of labour term. The latter allows introducing a heterogeneous labour force into the value-added function.

There is an abundant econometric literature on the estimation of relationships as the one depicted in Equation (1). In an attempt to reflect more accurately the production process 
inside the firm, specialists in the field have proposed specifications allowing e.g. for production inefficiencies or different elasticities of substitution between the factors of production. Since our focus is not on the production process itself, but rather on the comparison between productivities and wages for a set of workers' age groups, we use a simple Cobb-Douglas version of Equation (1), with substitution elasticities equal to one and the assumption of firms operating at the efficiency frontier. This restriction appears to be unproblematic as previous firm-level studies have shown that productivity coefficients obtained with a Cobb-Douglas structure are robust to other functional specifications (see, for instance, Hellerstein and Neumark, 2004). Equation (2) is the basic (Cobb-Douglas) valueadded function:

$$
\log \left(Y_{i}\right)=\log \left(A_{i}\right)+\alpha \log \left(K_{i}\right)+\beta \log \left(Q L_{i}\right)
$$

where $A_{i}$ is a constant. The parameters $\alpha$ and $\beta$ are the respective marginal productivities of each input factor. $Q L_{i}$ can be written as:

$$
Q L_{i}=L_{i}\left(1+\left(\theta_{i, j}-1\right) \sum_{j=1}^{G} \frac{L_{i, j}}{L_{i}}\right)
$$

where $L_{i}$ is the total labour force of the firm $i$ and $L_{i, j} / L_{i}$ the proportion of total labour force in age group $j$. Substituting Equation (3) into (2) allows for different marginal productivities for each of the $G$ age categories. If for age group $j$ the parameter $\theta_{j}$ is bigger (smaller) than unity, then this group has a higher (lower) marginal impact on productivity than the reference age category. If all groups have $\theta$ 's equal to one, then Equation (3) becomes $Q L_{i}=L_{i}$, i.e. labour is perfectly homogeneous.

As for the wage equation, Aubert and Crépon (2003) show that the average wage of firm $i$ can be expressed as:

$$
\bar{w}_{i}=\frac{\sum_{j=1}^{G} w_{i, j} L_{i, j}}{\sum_{j=1}^{G} L_{i, j}}=w_{i, 0}\left(\sum_{j=1}^{G} \frac{w_{i, j}}{w_{i, 0}} \frac{L_{i, j}}{L_{i}}\right)=w_{i, 0}\left(1+\sum_{j-\{0\}}^{G}\left(\frac{w_{i, j}}{w_{i, 0}}-1\right) \frac{L_{i, j}}{L_{i}}\right)
$$

where $w_{i, j}$ is the average wage of $L_{i, j}$ and $j=0$ the reference age category with the wage $w_{i, 0}$. 
Similar to the interpretation of $\theta$ in the production function, if the ratio $w_{j} / w_{0}$ is bigger (smaller) than unity, then the marginal impact of age group $j$ on the average wage in the firm is higher (lower) compared to the reference age category. Comparing marginal productivities and wage differentials across age groups boils down to comparing $\theta_{j}$ with the corresponding $w_{j} / w_{0}$.

\section{Data and descriptive statistics}

Our empirical analysis is based on a combination of two large data sets covering the years 1999-2006. The first, carried out by Statistics Belgium, is the 'Structure of Earnings Survey' (SES). It covers all firms operating in Belgium that employ at least 10 workers and with economic activities within sections $\mathrm{C}$ to $\mathrm{K}$ of the NACE Rev. 1 nomenclature. ${ }^{3}$ The survey contains a wealth of information, provided by the management of firms, both on the characteristics of the latter (e.g. sector of activity, number of workers, level of collective wage bargaining) and on the individuals working there (e.g. age, education, tenure, gross earnings, paid hours, sex, occupation). ${ }^{4}$ The SES provides no financial information. Therefore, it has been merged with a firm-level survey, the 'Structure of Business Survey' (SBS). The SBS, also conducted by Statistics Belgium, provides information on financial variables such as firm-level value added and gross operating surplus (per hour and per worker). The coverage of the SBS differs from that of the SES in that it does not cover the whole financial sector (NACE J) but only Other Financial Intermediation (NACE 652) and

\footnotetext{
${ }^{3}$ It thus covers the following sectors: i) mining and quarrying (C), ii) manufacturing (D), iii) electricity, gas and water supply (E), iv) construction (F), v) wholesale and retail trade, repair of motor vehicles, motorcycles and personal and household goods $(\mathrm{G})$, vi) hotels and restaurants $(\mathrm{H})$, vii) transport, storage and communication (I), viii) financial intermediation (J), and ix) real estate, renting and business activities (K).

${ }^{4}$ The SES is a stratified sample. The stratification criteria refer respectively to the region (NUTS-groups), the principal economic activity (NACE-groups) and the size of the firm. The sample size in each stratum depends on the size of the firm. Sampling percentages of firms are respectively equal to 10, 50 and 100 percent when the number of workers is lower than 50, between 50 and 99, and above 100. Within a firm, sampling percentages of employees also depend on size. Sampling percentages of employees reach respectively 100, 50, 25, 14.3 and 10 percent when the number of workers is lower than 20, between 20 and 50, between 50 and 99, between 100 and 199, and between 200 and 299. Firms employing 300 workers or more have to report information for an absolute number of employees. This number ranges between 30 (for firms with between 300 and 349 workers) and 200 (for firms with 12,000 workers or more). To guarantee that firms report information on a representative sample of their workers, they are asked to follow a specific procedure. First, they have to rank their employees in alphabetical order. Next, Statistics Belgium gives them a random letter (e.g. the letter O) from which they have to start when reporting information on their employees (following the alphabetical order of workers' names in their list). If they reach the letter $\mathrm{Z}$ and still have to provide information on some of their employees, they have to continue from the letter A in their list. Moreover, firms that employ different categories of workers, namely managers, blue- and/or white-collar workers, have to set up a separate alphabetical list for each of these categories and to report information on a number of workers in these different groups that is proportional to their share in total firm employment. For example, a firm with 300 employees (namely, 60 managers, 180 whitecollar workers and 60 blue-collar workers) will have to report information on 30 workers (namely, 6 managers, 18 white-collar workers and 6 blue-collar workers). For more details see Demunter (2000).
} 
Activities Auxiliary to Financial Intermediation (NACE 67). The merger of the SES and SBS datasets has been carried out by Statistics Belgium using firms’ social security numbers.

Three filters have been applied to the original dataset. The first derives its rationale from neoclassical productivity theory, which relies on the assumption that prices are economically meaningful. This is why we deleted firms that are publicly controlled and/or operating in predominantly public sectors from our sample. All regressions are therefore applied to privately controlled firms only. ${ }^{5}$

Second, we have eliminated firms with less than 10 observations, the reason for this being our use of average values at the firm level. In order to assure that averages (like, for instance, the proportion of employees in a specific occupation) are based on a minimum number of observations, we filtered out firms that provided information on less than 10 employees. ${ }^{6}$ This selection criterion leads to an average number of observations per firm in each year that is equal to 35 .

In addition to applying these two filters, the final sample on which our estimations are based consists only of firms that are observed in at least three consecutive years due to the inclusion of lagged differences in our models (see Section 5.1.). This leads to a bias towards big firms because of the sample design of the SES in which big firms are more likely to stay in the sample for several consecutive years than small firms (see footnote 6).

Our final sample consists of an unbalanced panel of 1735 firms yielding 5459 firmyear-observations during the six year period (1999-2006). It is representative of all mediumsized and large firms employing at least 10 employees within sections $\mathrm{C}$ to $\mathrm{K}$ of the NACE Rev. 1 nomenclature, with the exception of large parts of the financial sector (NACE J) and almost all the electricity, gas and water supply industry (NACE E).

The definition of earnings we use in the estimation correspond to the total gross wages, including premia for overtime, weekend or night work, performance bonuses, commissions and other premia. The work hours correspond to the total remunerated hours in the reference period (including paid overtime hours). The firm's value added per hour is measured at factor costs and calculated with the total number of hours effectively worked by the firm's employees. All variables in the SES-SBS are not self-reported by the employees, but provided by the firm's management and therefore more precise compared to employee or household surveys.

\footnotetext{
${ }^{5}$ More precisely, we eliminate firms for which public financial control exceeds $50 \%$. This exclusion reduces the sample size by less than $4 \%$.

${ }^{6}$ This selection is unlikely to affect our results as it leads to a small drop in sample size.
} 
[Insert Table 1 here]

Table 1 sets outs the means and standard deviations of selected variables. We observe that firms have a mean value added per hour worked of 55.51 Euros and that workers' mean gross hourly wage stands at 17.24 Euros. The age structure of the workforce within firms is on average composed by: $21 \%$ of workers younger than 30 years, $63 \%$ of prime-aged workers (between 30 and 49 years) and 16\% of older workers (with at least 50 years). We also find that $24 \%$ of workers are women, $54 \%$ are blue collar ${ }^{7}, 33 \%$ have a low level of education (i.e. lower secondary at most), 34\% work less than 38 hours per week, and 96\% have an open-ended employment contract. Moreover, almost $90 \%$ of workers in our sample are employed in relatively big firms (i.e. firms with at least 100 employees) essentially concentrated in the manufacturing sector (61 percent), hotels and restaurants (13 percent), wholesale and retail trade, repair of motor vehicles, motorcycles and personal and household goods (10 percent), construction (10 percent) and real estate, renting and business activities (9 percent).

\section{Specification and results}

\subsection{Functional specifications of the model}

In this section we describe the three different specifications of the Equations (2) and (4) that we estimated. We therefore move from the general form of the added-value and wage equations to a set of functional specifications.

The model formed by Equations (5) and (6) is our baseline specification and similar to the model in Hellerstein et al. (1999). The $\beta_{j}$ in Equation (5) is the relative marginal impact of age group $j$ (note that $\beta_{j}$ corresponds to $\theta_{j}$ - 1 in Equation (3)). In Equation (6), $\beta_{j}^{\circ}$ is the relative marginal impact of age share $j$ on the average wage $\left(\beta_{j}^{\circ}\right.$ corresponds to $w_{j} / w_{0}-1$ in Equation (4)). The terms $\mu_{i, t}$ and $\mu_{i, t}^{\circ}$ represent the error terms.

\footnotetext{
7 Blue-collar occupations include "Craft and related trades workers", "Plant and machine operators, and assemblers”, and "Elementary occupations”.
} 


$$
\begin{aligned}
& \log (\text { VALUEADDED / HOURS })_{i, t}= \\
& \beta_{0}+\sum_{t-\{0\}}^{5} \alpha_{t} I^{t}(Y E A R)_{i, t}+\sum_{j-\{0\}}^{7} \beta_{j} \text { AGEGROUP }{ }_{j, i, t} \\
& +\sum_{k-\{0\}}^{3} \gamma_{k} I^{k}(\text { FIRMAGE })_{i, t}+\sum_{m-\{0\}}^{8} \delta_{m} I^{m}(\text { NACE } 2)_{i, t}+\sum_{s-\{0\}}^{5} v_{s} I^{s}(\text { FIRMSIZE })_{i, t} \\
& +\sum_{e-\{0\}}^{5} \varsigma_{e} \text { EDUCATION }_{e, i, t}+\eta \text { WOMEN }_{i, t} \\
& +\sum_{p-\{0\}}^{6} \varphi_{p} \text { OCCUPATION }_{p, i, t}+\sum_{q-\{0\}}^{2} \lambda_{q} \text { WORKDURATION }_{q, i, t} \\
& +\rho \text { NON - STANDARDCONTRACT } T_{i, t}+\mu_{i, t} \\
& \log (\text { TOTALWAGES / HOURS })_{i, t}= \\
& \beta_{0}^{\circ}+\sum_{t-\{0\}}^{5} \alpha_{t}^{\circ} I^{t}(Y E A R)_{i, t}+\sum_{j-\{0\}}^{7} \beta_{j}^{\circ} A_{G E G R O U P}^{j, i, t} \\
& +\sum_{k-\{0\}}^{3} \gamma_{k}^{\circ} I^{k}(\text { FIRMAGE })_{i, t}+\sum_{m-\{0\}}^{8} \delta_{m}^{\circ} I^{m}(\text { NACE } 2)_{i, t}+\sum_{s-\{0\}}^{5} v_{s}^{\circ} I^{s}(\text { FIRMSIZE })_{i, t} \\
& +\sum_{e-\{0\}}^{5} \varsigma_{e}^{\circ} \operatorname{EDUCATION}_{e, i, t}+\eta^{\circ} \text { WOMEN }_{i, t} \\
& +\sum_{p-\{0\}}^{6} \varphi_{p}^{\circ} \text { OCCUPATION }_{p, i, t}+\sum_{q-\{0\}}^{2} \lambda_{q}^{\circ} \text { WORKDURATION }_{q, i, t} \\
& +\rho^{\circ} \mathrm{NON}-\mathrm{STANDARDCONTRACT_{i,t }}+\mu_{i, t}^{\circ}
\end{aligned}
$$

The dependent variable in Equation (5) is the total value added by the firm $i$ in period $t$, divided by the total number of work hours (taking into account paid overtime hours) that have been declared for the same period. The dependent variable in Equation (6) is firm i's average hourly gross wage (including premia for overtime, weekend or night work, performance bonuses, commissions and other premia). It is obtained by dividing the firm's total wage bill by the total number of work hours. Hence, the dependent variables in the estimated equations are firm averages of added-value and wages on an hourly basis. The main independent variables are the shares of hours worked by each age category in total work hours, AGEGROUP ${ }_{j, i, t .}$. This is a better employment indicator than the number of employees in each age category since it takes into account age differences in working time. We split employees of a firm into three age groups (i.e. $<30,30-49,50+$ ) and consider the share of prime-aged workers as our reference category. These age categories provide a good representation of the different stages in the individual life cycle. Indeed, as noted by Malmberg et al. (2005), one may suppose that workers younger than 30 years are more 
healthy, mobile and motivated individuals. The middle-aged workers might (i) have heavier family responsibilities, (ii) be more experienced and (iii) hold important management responsibilities. Workers older than 50 years of age could (i) have a good knowledge of themselves (e.g. they know how to be productive with a minimum of effort), (ii) have a better matching of their abilities with their job preferences, (iii) be less motivated to learn and (iv) suffer a weakening of their health.

In addition to the age shares in total work hours, we also included a set of variables controlling for observable characteristics of the firm and its labour force. Since the capital stock of firm $j$ is not available in the SES-SBS, capital is proxied with a dummy variable for nine economic sectors at the one-digit level of the NACE $\left(I^{m}(N A C E 1)_{i, t}\right)$. This is likely to compensate for the omission of capital since the latter tends to be correlated with the type of activity of the firm. Given the results reported in the empirical literature, van Ours and Stoeldraijer (2010) argue that the omission of the exact capital stock does not affect the estimates of production functions on firm-level data since the corresponding productivity effects tend to be small (cf. Hellerstein et al. 1999; Aubert and Crépon, 2003; Dostie, 2006). Additional dummy controls are $I^{k}(\text { FIRMAGE })_{i, t}$, indicating the age of the firm and $I^{s}(\text { FIRMSIZE })_{i, t}$, the firm's size as measured by the number of employees.

We also control for the composition of the labour force of firm $i$ : EDUCATION $N_{e, i, t}$ are the proportions of educational groups inside the firm; $W O M E N_{i, t}$ is the share of female workers; OCCUPATION $N_{p, i, t}$ are the proportions of different occupational groups; $W_{O R K D U R A T I O N}^{q, i, t}$ are the shares of part-time and medium-time workers; NONSTANDARDCONTRACT $T_{i, t}$ is the proportion of workers with contracts in which the employment term is not unlimited (for the modalities of all control variables see Table 1). The estimated equations also include dummies $I^{t}(Y E A R)_{i, t}$ for the years of observation.

Estimating Equations (5) and (6) yields insight into the shape and significance of age productivity- and wage profiles, but it does not allow to test directly whether the difference between the added-value and wage coefficients for a given occupation is statistically significant. A simple method to obtain a test for the significance of productivity-wage gaps has been proposed by van Ours and Stoeldraijer (2010). We apply a similar approach and estimate a model in which the difference between firm i's hourly added-value and average wage is regressed on the same set of explanatory variables as in Equations (5) and (6). This produces age coefficients that measure directly the size and significance of each age group productivity-wage gap.

We have estimated Equations (5) and (6), as well as the productivity-wage gap, with 
two different methods. The baseline regression is a pooled Ordinary Least Squares (OLS) estimator with robust standard errors (we use a Huber/White/sandwich estimate of variance, i.e. the errors are robust to heteroskedasticity and serial correlation, cf. Wooldridge, 2002). This estimator is based on both the cross-section variability between firms and the longitudinal variability within firms over time.

Pooled OLS estimators of value-added models have been criticized for their potential "heterogeneity bias" (Aubert and Crépon, 2003; p. 116). This bias is due to the fact that firm productivity depends to a large extent on firm-specific, time-invariant characteristics that are not measured in micro-level surveys. As a consequence, the age coefficients of these estimators might be biased since unobserved firm characteristics may affect simultaneously the firm's level of added value and its workforce age composition. This is referred to as a problem of spurious correlation and could be caused by factors such as an advantageous location, firm-specific assets like the ownership of a patent or other firm idiosyncrasies. One way to deal with unobserved time-invariant heterogeneity of firms is to estimate Equations (5) and (6), as well as the productivity-wage gap, in first differences (with heteroskedasticity and serial correlation robust standard errors). First differences do not estimate the level of productivity of firm $i$, but the change in productivity. Time-invariant heterogeneity is by definition not linked to changes in productivity and therefore controlled for. Since the first differences estimator eliminates firm characteristics that remain unchanged during the observation period, time-invariant control variables are not included in this specification.

In addition to pooled OLS and first differences estimations, we have carried out a series of robustness tests to examine whether our results are sensitive to: a) the potential endogeneity of the workforce age structure, b) the inclusion of dynamics in the model and c) the use of a smaller set of control variables. The outcome of these tests (reported in Section 5.3.) shows that the main conclusions presented in the next section are robust to alternative specifications.

\subsection{Estimation results}

We first estimate equations (5) and (6), as well as the productivity wage gap, by pooled OLS. Results regarding the age-productivity profile are presented in the second column of Table 2. They show that workers younger than 30 are significantly less productive than prime age and older workers. In contrast, the productivity of workers older than 49 is not found to differ significantly from that of middle-aged workers. The regression coefficient associated to the 
share of young workers is equal to -0.17 . This means that if the fraction of younger workers within a firm increases by one unit (i.e. one percentage point), productivity decreases on average by 0.17 percent (i.e. $-0.017 * 0.01=-0.0017=-0.17$ percent). Regression coefficients for the shares of young and older workers can thus be roughly interpreted as elasticities between productivity and fractions of workers by age groups. Yet, one should keep in mind that a change in one group of (young, prime age or older) workers modifies the incidence of workers in the other groups (van Ours and Stoeldraijer, 2010). Turning to the relationship between age and wage, results show (see column 3 of Table 2) that a one percentage point increase in the share of young workers decreases mean hourly wages within firms on average by 0.32 percent. On the opposite, mean hourly wages are found to increase on average by 0.11 percent following a one percentage point increase in the fraction of older workers. Findings thus support the existence of a significant upward sloping age-wage profile. The comparison of estimates for the age-productivity and age-wage profiles suggests that young workers are paid below their marginal productivity while workers older than 49 would be overpaid. Results from the productivity-wage gap regression (reported in column 4 of Table 2) support this hypothesis. Indeed, the impact of the share of young (older) workers on the productivity-wage gap is found to significantly positive (negative).

\section{[Insert Table 2 here]}

However, these results should be interpreted with caution. Indeed, they may suffer from the fact that time-invariant unobserved workplace characteristics are not accounted for. Indeed, the Breusch and Pagan (1980) Lagrangian multiplier is 4735.88 for the added value and 4060.36 for the wage equation, which is why we refute the adequateness of pooled OLS for the estimation of equations (5) and (6). We therefore re-estimated the model, as well as the productivity wage gap, in first differences. Results for the age-wage profile are not very different than those in the OLS regression (see column 6 of Table 2). They again highlight that average hourly wages within firms increase significantly and monotonically with mean workers' age. Yet, the regression coefficient associated to the share of young workers drops from -0.32 to -0.15 while that for the fraction of older workers increases from 0.11 to 0.15 . Findings for the age-productivity profile after controlling for firm fixed effects are quite different from those obtained with OLS (see column 5 of Table 2). Indeed, results now show that workers older than 49 are significantly less productive than prime age and young workers. Moreover, we find no evidence anymore for the fact that young workers would be 
less productive than prime age workers. Overall, our results lend support to the existence of a mechanism of deferred compensation over the life-cycle (Lazear, 1979). Indeed, results from our productivity-wage gap regression (see column 7 of Table 2) again highlight the "underpayment" of workers younger than 30 and the "overpayment" of workers older than 49.

\subsection{Robustness tests}

An array of tests has been carried out to assess the robustness of the results presented in the previous section. The main results stand up to a range of alternative specifications.

\section{Potential endogeneity of age shares}

A first issue to consider is the potential endogeneity of the workforce age structure. The point is that any unobserved productivity shock might generate correlated changes in the workforce age structure and labour productivity that are not due to the aging of the workforce per se. For example, one might expect that a firm undergoing a negative productivity shock would prefer not to hire new individuals, which would increase the age of the workforce. Hence, the correlation that we could find, using first differences estimations, between a decrease of firm productivity and the rise of the share of older workers could be purely spurious. A way to address this simultaneity problem is to use instruments that are correlated with the problematic explanatory variables and uncorrelated with the exogenous shocks (i.e. the error term).

To explore the acuteness of the simultaneity problem in our data, we have estimated Equations (5) and (6), as well as the productivity-wage gap, in first differences and instrumented the (differenced) age shares with the one-period lag of the level of these shares. In other words, the lagged level of age shares is assumed to be correlated with future values of the instrumented variables but not with the exogenous shocks. ${ }^{8}$ We estimated the IV firstdifferenced equations using the Generalized Method of Moments (GMM) with a Newey-West variance-covariance matrix and standard errors that are robust to heteroskedasticity and serial correlation. This IV approach has been applied to productivity and wage equations by Aubert and Crépon (2003) and is now standard in the literature (cf. van Ours, 2009; Göbel and

\footnotetext{
${ }^{8}$ We have experimented with a larger set of instruments, for instance by including lags of age shares for $t-2$ and $t$-3. However, only the smaller set including one-period lags passed the test of weak identification.
} 
Zwick, 2009). To examine the reliability of our results, we have computed the usual diagnostic tests for instrumental variables. First, the Kleibergen-Paap statistic for underidentification tests whether the equation is identified, i.e. whether the excluded instruments are all relevant. The null hypothesis in this test is that the equation is underidentified. Second, the Kleibergen-Paap statistic for weak identification is a Wald F statistic testing whether the excluded instruments are sufficiently correlated with the endogenous regressors (the null hypothesis being weak identification). Since a rejection rule for this test has yet to be established, we rely on the "rule of thumb" that weak identification is problematic for Fstatistics smaller than 10 (cf. van Ours and Stoeldraijer, 2010). Finally, we compute an endogeneity test with the null hypothesis that the age shares can actually be treated as exogenous. The test is based on the difference of two Sargan-Hansen statistics: one for the equation in which the age shares are treated as endogenous, and one in which they are treated as exogenous. If the null hypothesis of this test cannot be rejected, then instrumentation is actually not necessary.

The results in Appendix 1 indicate that under- and weak identification is unproblematic in our case: we reject the hypothesis of under-identification at the one percent level and the Kleibergen-Paap statistics for weak identification are above 10. Moreover, we cannot reject the hypothesis that age shares can actually be treated as exogenous: the corresponding p-values are 0.78 (added-value), 0.87 (wage) and 0.74 (productivity-wage gap). This means that instrumentation is actually not necessary since there appears to be no endogeneity in the age shares once we control for time-invariant unobserved firm characteristics by taking first differences. The results for GMM-IV reported in Appendix 1 should therefore be read with the disclaimer that the IV estimates are less efficient compared to our baseline model in first differences and that instrumentation is actually not necessary in our case.

\section{Dynamic specification}

Another problem to consider is the potential state dependence of the dependent variable. To do so, we estimate a dynamic version of our models in first differences by including oneperiod lag of the dependent variable among the regressors. In other words, we allow the dependent variable to be not only related to contemporary inputs, but also to be a function of its own value in the previous period (Arellano and Bond, 1991; Göbel and Zwick, 2009). The lagged dependent variable is found to be highly significant in the three regressions and the 
"goodness of fit" of our models is improved (see Appendix 2). This being said, results still confirm conclusions from the static specification. However, the size of the regression coefficients associated to the age share variables is somewhat reduced. Indeed, the detrimental effect of older workers on firm productivity drops from -0.12 to -0.09 . Moreover, mean hourly wages are now found to increase (decrease) on average by 0.13 percent following a one percentage point increase in the fraction of older (younger) workers. Overall, this leads to a (slightly) smaller “overpayment” (“underpayment”) of older (young) workers. More precisely, dynamic results suggest that a one percentage point increase in the share of workers younger than 30 (older than 49) increases (decreases) the productivity-wage gap within firms on average by 0.15 percent ( 0.21 percent).

\section{Specification without worker controls}

Our baseline specification controls for the composition of the firm's labour force in terms of educational attainment, gender ratio, occupational shares, the extent of medium- and parttime work and the proportion of non-standard work contracts (see section 5.1.). This is the standard procedure to create a ceteris paribus effect for the age variable. An alternative perspective on our question can be obtained by regressing our dependent variables on age shares without these control variables in the model. In this case, an age group composition in terms of education or occupation is viewed as a constituent element of its impact on productivity, wages and productivity-wage gaps instead of isolating the age coefficients from these characteristics.

We have computed the first differences estimator (both static and dynamic) excluding worker controls and find our conclusions unaltered, although the size of the regression coefficients associated to the age share variables are generally bigger in absolute value (see Appendix 3).

\section{Conclusion}

This paper provides one of the first attempts to disentangle the relationship between age, wage and productivity. More precisely, we examine how changes in the proportion of young (16-29 years), middle-aged (30-49 years) and older (more than 49 years) workers affect the productivity of firms and investigate the presence of productivity-wage gaps for these age groups. To do so, we use longitudinal matched employer-employee data covering the Belgian 
private sector over the period 1999-2006. Our data allows to tackle a range of measurement issues that have hampered the existing literature on our question: the panel data provides accurate information on average productivity and wages within firms; controls for a wide range of worker and firm characteristics; includes age variables in terms of hours worked rather than on a per capita basis; and permits to deal with unobserved firm heterogeneity, the endogeneity of age shares and state dependence of firm productivity and wages.

Results based on our preferred specification suggest that workers older than 49 are significantly less productive than prime age and young workers. By contrast, the productivity of middle-aged workers is not found to be significantly different from that of young workers. Findings further indicate that average hourly wages within firms increase significantly and monotonically with mean workers' age. Overall, this leads to the conclusion that young workers are paid below their marginal productivity while older workers appear to be “overpaid”.

These results may have important policy implications. The fact that older workers are found to be less productive than young and prime-age workers suggests that policies aiming to improve the employment rate of older people (e.g. abolishing early retirement schemes or lifting the legal retirement age) may be detrimental for firm productivity. Policies "encouraging" older workers to retain in work or to return to work should thus be accompanied by efficient training programmes. More effort should also be devoted to the improvement of working conditions so as to reduce the impact of aging on workers' physical and mental health (and productivity).

However, considering our results from a "lifetime” perspective may lead to somewhat different conclusions. The point is that workers are found to be "underpaid" when young and “overpaid” when older. As highlighted by Lazear (1979), this sequencing of pay may be beneficial to both employers and employees in internal labour markets. Indeed, it is the present value of career compensation that would matter in these markets. Put differently, the adoption of a deferred compensation scheme would improve employees' productivity (because it stimulates workers' effort, reduces monitoring costs and enables firms to hire and retain the best employees) and hence allow firms to pay higher present value career compensation than otherwise (Ehrenberg and Smith, 2003).

Overall, this life-cycle perspective suggests that the observed under- and overpayment of respectively young and older workers in the Belgium private sector should not be harmful to employers with internal labour markets, except if the present value of career compensation exceeds that of marginal productivities. The same should be true for their 
employees unless: i) career compensation falls short of marginal product value, ii) the firm goes bankrupt before they retire, iii) they are fired before they reach an age at which they benefit from potential end-of-career overpayment. The latter reason should not be neglected because deferred compensation schemes may incite firms to renege, i.e. to dismiss workers before they get older so as to maximise their profits (at least in the short run).

Finally, one should keep in mind that a significant fraction of firms do not operate with internal labour markets (Lazear and Oyer, 2003). In external labour markets, workers and firms are more concerned with the immediate relation between pay and productivity. The optimality of a deferred compensation scheme on that portion of the labour market is therefore less straightforward.

\section{References}

Andersson, B., Holmlund, B., and Lindh, T. (2002), “Labor productivity, age and education in Swedish mining and manufacturing 1985-96”, Uppsala University, Sweden.

Arellano, M. and Bond, S. (1991), "Some tests of specification for panel data: Monte Carlo evidence and an application to employment equations”, Review of Economic Studies, Vol. 58 No. 2, pp. 277-297.

Aubert, P. and Crépon, B. (2003), "La productivité des salariés âgés: une tentative d'estimation”, Economie et Statistique, No. 368, pp. 95-119.

Bartel, A. and Sichermann, N. (1993), “Technological change and retirement decision of older workers”, Journal of Labor Economics, Vol. 11 No. 1, pp. 162-183.

Bertschek, I. and Meyer, J. (2008), “Do older workers lower IT-enabled productivity? Firmlevel evidence from Germany”, DRUID Working Paper No. 08-17, Copenhagen.

Borsch-Supan, A. and Alexander, L. (2010), “Old Europe ages: Reforms and reform backlashes”, NBER Working Paper No. 15744, Cambridge, MA.

Breusch, T. and Pagan, A. (1980), "The LM test and its application to model specification in econometrics”, Review of Economic Studies, Vol. 47 No. 1, pp. 239-254.

Brooke, L. (2003), "Human resources costs and benefits of maintaining a mature-age workforce”, International Journal of Manpower, Vol. 24 No. 3, pp. 260-284.

Cardoso, A., Guimarães, P. and Varejão, J. (2010), “Are older workers worthy of their pay? An empirical investigation of age-productivity and age-wage nexuses”, IZA Discussion Paper No 5121, Bonn.

Czaja, S. and Sharit, J. (1998), “Ability performance relationship as a function of age and 
task experience for a data entry task”, Journal of Experimental Psychology: Applied, Vol. 4 No. 4, pp. 332-351.

Demunter, C. (2000), "Structure and distribution of earnings survey: Analysis 1995", Statistics Belgium Working Paper, Brussels.

Dostie, B. (2006), “Wages, productivity and aging”, IZA Discussion Paper No. 2496, Bonn.

Economic Policy Committee and the European Commission (2006), “The impact of aging on public expenditure: projections for the EU25 Member States on pensions, health care, longterm care, education and unemployment transfers (2004-2050)”, Special Report No. 1/2006, Brussels.

Ehrenberg, R. and Smith, R. (2003), Modern Labor Economics. Theory and Public Policy, Addison-Wesley, Boston.

European Commission (2007), Employment in Europe 2007, Luxembourg.

Göbel, C. and Zwick, T. (2009), “Age and productivity - Evidence from linked employer employee data”, ZEW Discussion Paper No. 09-020, Mannheim.

Grund, C. and Westergaard-Nielsen, N. (2005), “Age structure of the workforce and firm performance”, IZA Discussion Paper No 1818, Bonn.

Haegeland, T. and Klette, T. (1999), "Do higher wages reflect higher productivity? Education, gender and experience premiums in a matched plant-worker data set,” in: Haltiwanger, J., Lane, J., Spletzer, J., Theeuwes, J. and. Troske, K. (eds.), The Creation and Analysis of Employer-employee Matched Data, Elsevier Science, North-Holland, pp. 231-259.

Haltiwanger, J., Lane, J. and. Spletzer, J. (1999), “Productivity differences across employers. The roles of employer size, age and human capital”, American Economic Review, Vol. 89 No. 2, pp. 94-98.

Hellerstein, J. and Neumark, D. (1995), “Are earnings profiles steeper than productivity profiles? Evidence from Israeli firm data”, Vol. 30 No. 1, Journal of Human Resources, pp. 89-112.

Hellerstein, J. and Neumark, D. (2004), "Production function and wage equation estimation with heterogeneous labor: Evidence from a new matched employer-employee data set”, NBER Working Paper No. 10365, Cambridge, MA.

Hellerstein, J., Neumark D., and Troske, K. (1999), "Wages, productivity and worker characteristics: Evidence from plant-level production functions and wage equations”, Journal of Labor Economics, Vol. 17 No. 2, pp. 409-446.

Ilmakunnas, P. and Maliranta, M. (2005), “Technology, labour characteristics and wageproductivity gaps”, Oxford Bullettin of Economic and Statistics, Vol. 67 No. 5, pp. 623- 
644.

Itzin, C., Phillipson C., and Laczko, F. (1994), “Age barriers at work - Maximizing the potential of mature and older workers [Review]”, Journal of Social Policy, Vol. 23, pp. 119.

Johnson, W. (1978), “A theory of job shopping”, Quarterly Journal of Economics, Vol. 92 No.2, pp. 261-277.

Jovanovic, B. (1979), “Job matching and the theory of turnover”, Journal of Political Economy, Vol. 87 No. 5, pp. 972-990.

Lallemand, T. and Rycx, F. (2009), “Are older workers harmful for firm productivity?”, De Economist, Vol. 157 No.3, pp. 273-292.

Lazear, E. (1979), “Why is there mandatory retirement?”, Journal of Political Economy Vol. 87 No. 6, pp. 1261-1284.

Lazear E. and Oyer, P. (2003), "Internal and external labour markets: A personnel economics approach”, NBER Working Paper No. 10191, Cambridge (Ма.).

Malmberg, B., Lindh, T., and Halvarsson, M. (2005), "Productivity consequences of workforce aging - Stagnation or horndal effect?”, Working Paper No. 2005-17, Institute for Futures Studies, Stockholm.

Mincer, J, (1974), Schooling, Experience and Earnings, NBER Press, New-York.

Ng, T. and Feldman, D. (2008), "The relationship of age to ten dimensions of job performance”, Journal of Applied Psychology, Vol. 93 No. 2, pp. 392-423.

OECD (2006), Aging and Employment Policies - Live Longer, Work Longer, Paris.

Prskawetz, A., Mahlberg B., Skirbekk, V., Freund, I., Winkler-Dworak, M., Lindh, T., Malmberg, B., Nordström, O., and Andersson, F. (2006), “The impact of population aging on innovation and productivity growth in Europe”, Research report No. 28 for the European Commission, Employment, Social Affairs and Equal Opportunities DG, Vienna Institute of Demography.

Shepard, R. (1999), “Age and physical work capacity”, Experimental Aging Research, Vol. 25 No. 4, pp. 331-343.

Skirbekk, V. (2003), “Age and individual productivity: A literature survey”, Technical Report No. 2003-028, Max Planck Institute for Demographic Research.

Tang, J. and MacLeod, C. (2006), "Labour force aging and productivity performance in Canada”, Canadian Journal of Economics, Vol. 39 No. 2, pp. 583-603.

van Ours, J. (2009), “Will you still need me - When I’m 64?”, IZA Discussion Paper No. 4264, Bonn. 
van Ours, J. and Stoeldraijer, L. (2010), “Age, wage and productivity”, IZA Discussion Paper No. 4765, Bonn.

Walewski, M. (2008), "Differences in the productivity levels of older workers in the EU - A cross country analysis of the age - wage relationship”, ENEPRI Research Report No. 49 AIM-WP6.

Wooldridge, J. (2002), Econometric Analysis of Cross Section and Panel Data, MIT Press. 
Table 1. Descriptive statistics for firms (1999-2006)

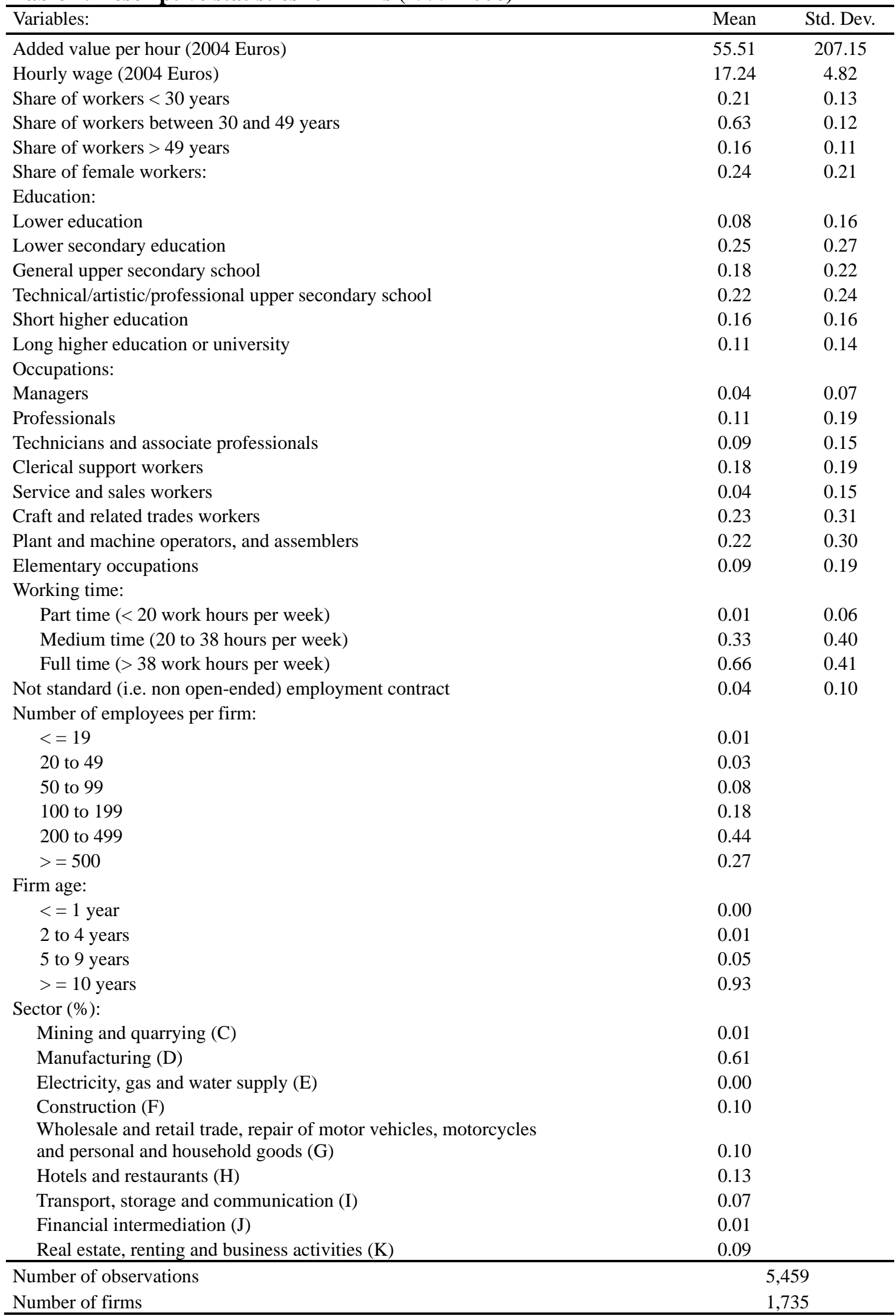


Table 2: Estimation results

\begin{tabular}{|c|c|c|c|c|c|c|}
\hline \multirow[b]{2}{*}{ Dependent variable: } & \multicolumn{3}{|c|}{ Pooled OLS } & \multicolumn{3}{|c|}{ First differences } \\
\hline & $\begin{array}{c}\text { Value added } \\
\text { per hour worked } \\
(\ln )\end{array}$ & $\begin{array}{c}\text { Mean wage per hour } \\
\text { worked (ln) }\end{array}$ & $\begin{array}{l}\text { Value added-wage } \\
\text { gap (ln) }\end{array}$ & $\begin{array}{c}\text { Value added } \\
\text { per hour worked } \\
(\ln )\end{array}$ & $\begin{array}{l}\text { Mean wage per } \\
\text { hour worked (ln) }\end{array}$ & $\begin{array}{l}\text { Value added- } \\
\text { wage gap (ln) }\end{array}$ \\
\hline Share (Age < 30) & $\begin{array}{c}-0.17^{* * * *} \\
(0.06)\end{array}$ & $\begin{array}{c}-0.32 * * * \\
(0.02)\end{array}$ & $\begin{array}{c}0.15 * * * \\
(0.06)\end{array}$ & $\begin{array}{c}0.03 \\
(0.04)\end{array}$ & $\begin{array}{c}-0.15^{* * *} \\
(0.02)\end{array}$ & $\begin{array}{c}0.17 * * * \\
(0.05)\end{array}$ \\
\hline Share (Age $>50$ ) & $\begin{array}{c}0.00 \\
(0.07)\end{array}$ & $\begin{array}{c}0.11^{* * *} \\
(0.03)\end{array}$ & $\begin{array}{l}-0.11^{*} \\
(0.06)\end{array}$ & $\begin{array}{c}-0.12 * * \\
(0.05)\end{array}$ & $\begin{array}{c}0.15 * * * \\
(0.02)\end{array}$ & $\begin{array}{c}-0.26^{* * * *} \\
(0.05)\end{array}$ \\
\hline Worker characteristics ${ }^{\mathrm{a}}$ & Yes & Yes & Yes & Yes & Yes & Yes \\
\hline Firm characteristics ${ }^{\mathrm{b}}$ & Yes & Yes & Yes & $\begin{array}{c}\text { Dropped } \\
\text { (Time invariant) }\end{array}$ & $\begin{array}{c}\text { Dropped } \\
\text { (Time invariant) }\end{array}$ & $\begin{array}{c}\text { Dropped } \\
\text { (Time invariant) }\end{array}$ \\
\hline Year dummies (7) & Yes & Yes & Yes & Yes & Yes & Yes \\
\hline F statistic & 47.89 & 192.31 & 9.68 & 1.55 & 48.85 & 17.85 \\
\hline R squared & 0.29 & 0.67 & 0.07 & 0.01 & 0.32 & 0.06 \\
\hline Number of observations & 5,459 & 5,459 & 5,459 & 5,459 & 5,459 & 5,459 \\
\hline Number of firms & 1,735 & 1,735 & 1,735 & 1,735 & 1,735 & 1,735 \\
\hline
\end{tabular}

Notes: $* * * / * * / *$ significant at the 1, 5 and 10\% level. Robust standard errors are reported between brackets.

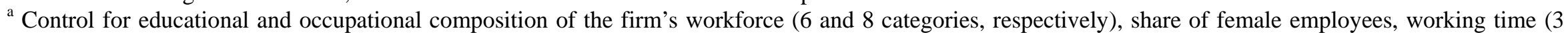
categories) and share of non-standard work contracts.

${ }^{\mathrm{b}}$ Control for firm size (5 dummies), firm vintage age (3 dummies) and industry (8 dummies). 


\begin{tabular}{|c|c|c|c|}
\hline Dependent variable: & $\begin{array}{c}\text { Value added } \\
\text { per hour worked } \\
\text { (ln) }\end{array}$ & $\begin{array}{l}\text { Mean wage per hour } \\
\text { worked (ln) }\end{array}$ & $\begin{array}{l}\text { Value added-wage } \\
\text { gap (ln) }\end{array}$ \\
\hline Share (Age < 30) & $\begin{array}{c}0.00 \\
(0.10)\end{array}$ & $\begin{array}{c}-0.16 * * * \\
(0.04)\end{array}$ & $\begin{array}{c}0.16 \\
(0.11)\end{array}$ \\
\hline Share (Age > 50) & $\begin{array}{l}-0.03 \\
(0.14)\end{array}$ & $\begin{array}{c}0.13^{* * *} \\
(0.05)\end{array}$ & $\begin{array}{l}-0.16 \\
(0.14)\end{array}$ \\
\hline Worker characteristics ${ }^{\mathrm{a}}$ & Yes & Yes & Yes \\
\hline Firm characteristics ${ }^{\mathrm{b}}$ & $\begin{array}{c}\text { Dropped } \\
\text { (Time invariant) }\end{array}$ & $\begin{array}{c}\text { Dropped } \\
\text { (Time invariant) }\end{array}$ & $\begin{array}{c}\text { Dropped } \\
\text { (Time invariant) }\end{array}$ \\
\hline Year dummies (7) & Yes & Yes & Yes \\
\hline F statistic & 1.17 & 36.78 & 12.90 \\
\hline R squared & 0.00 & 0.32 & 0.06 \\
\hline Under-identification $^{\mathrm{C}}$ & 0.00 & 0.00 & 0.00 \\
\hline Weak identification $^{\mathrm{d}}$ & 259 & 259 & 259 \\
\hline Endogeneity ${ }^{\mathrm{e}}$ & 0.78 & 0.87 & 0.74 \\
\hline Number of observations & 5,459 & 5,459 & 5,459 \\
\hline Number of firms & 1,735 & 1,735 & 1,735 \\
\hline \multicolumn{4}{|c|}{$\begin{array}{l}\text { Notes: } * * * / * * / * \text { significant at the } 1,5 \text { and } 10 \% \text { level. Robust standard errors are reported be } \\
\text { brackets. } \\
\text { a Control for educational and occupational composition of the firm's workforce ( } 6 \text { and } 8 \text { cate } \\
\text { respectively), share of female employees, working time ( } 3 \text { categories) and share of non-standarc } \\
\text { contracts. } \\
\text { b Control for firm size ( } 5 \text { dummies), firm vintage age ( } 3 \text { dummies) and industry ( } 8 \text { dummies). } \\
{ }^{c} \text { p-value associated to Kleibergen-Paap rk LM statistic. } \\
{ }^{d} \text { Kleibergen-Paap rk Wald F statistic }\end{array}$} \\
\hline
\end{tabular}


Appendix 2: First differences with (one year) lagged dependent variable

\begin{tabular}{|c|c|c|c|}
\hline Dependent variable: & $\begin{array}{c}\text { Value added } \\
\text { per hour worked } \\
(\ln )\end{array}$ & $\begin{array}{l}\text { Mean wage per hour } \\
\text { worked (ln) }\end{array}$ & $\begin{array}{l}\text { Value added-wage } \\
\text { gap (ln) }\end{array}$ \\
\hline Share (Age < 30) & $\begin{array}{c}0.02 \\
(0.04)\end{array}$ & $\begin{array}{c}-0.13^{* * *} \\
(0.02)\end{array}$ & $\begin{array}{c}0.15^{* * *} \\
(0.05)\end{array}$ \\
\hline Share (Age > 50) & $\begin{array}{l}-0.09 * * \\
(0.05)\end{array}$ & $\begin{array}{c}0.13^{* * *} \\
(0.02)\end{array}$ & $\begin{array}{c}-0.21 * * * \\
(0.05)\end{array}$ \\
\hline $\begin{array}{l}\text { One year lagged dependent } \\
\text { variable }\end{array}$ & $\begin{array}{c}-0.34^{* * *} \\
(0.08)\end{array}$ & $\begin{array}{c}-0.32 * * * \\
(0.02)\end{array}$ & $\begin{array}{c}-0.36 * * * \\
(0.07)\end{array}$ \\
\hline Worker characteristics ${ }^{\mathrm{a}}$ & Yes & Yes & Yes \\
\hline Firm characteristics $^{\mathrm{b}}$ & $\begin{array}{c}\text { Dropped } \\
\text { (Time invariant) }\end{array}$ & $\begin{array}{c}\text { Dropped } \\
\text { (Time invariant) }\end{array}$ & $\begin{array}{c}\text { Dropped } \\
\text { (Time invariant) }\end{array}$ \\
\hline Year dummies (7) & Yes & Yes & Yes \\
\hline F statistic & 2.36 & 65.03 & 20.25 \\
\hline $\mathrm{R}$ squared & 0.13 & 0.41 & 0.19 \\
\hline Number of observations & 5,459 & 5,459 & 5,459 \\
\hline Number of firms & 1,735 & 1,735 & 1,735 \\
\hline
\end{tabular}

Notes: $* * * / * * *$ significant at the 1, 5 and $10 \%$ level. Robust standard errors are reported between brackets.

${ }^{\text {a }}$ Control for educational and occupational composition of the firm's workforce (6 and 8 categories, respectively), share of female employees, working time (3 categories) and share of non-standard work contracts.

${ }^{\mathrm{b}}$ Control for firm size (5 dummies), firm vintage age (3 dummies) and industry (8 dummies). 
Appendix 3: First differences without worker control variables

\begin{tabular}{|c|c|c|c|c|c|c|}
\hline \multirow[b]{2}{*}{ Dependent variable: } & \multicolumn{3}{|c|}{ Static specification } & \multicolumn{3}{|c|}{ Dynamic specification } \\
\hline & $\begin{array}{c}\text { Value added } \\
\text { per hour worked } \\
(\ln )\end{array}$ & $\begin{array}{l}\text { Mean wage per hour } \\
\text { worked (ln) }\end{array}$ & $\begin{array}{l}\text { Value added-wage } \\
\text { gap (ln) }\end{array}$ & $\begin{array}{c}\text { Value added } \\
\text { per hour worked } \\
(\ln )\end{array}$ & $\begin{array}{l}\text { Mean wage per } \\
\text { hour worked (ln) }\end{array}$ & $\begin{array}{l}\text { Value added- } \\
\text { wage gap (ln) }\end{array}$ \\
\hline Share (Age < 30) & $\begin{array}{c}0.02 \\
(0.04)\end{array}$ & $\begin{array}{c}-0.19 * * * \\
(0.02)\end{array}$ & $\begin{array}{c}0.20 * * * \\
(0.05)\end{array}$ & $\begin{array}{c}0.02 \\
(0.04)\end{array}$ & $\begin{array}{c}-0.16^{* * *} \\
(0.02)\end{array}$ & $\begin{array}{c}0.18 * * * \\
(0.05)\end{array}$ \\
\hline Share (Age > 50) & $\begin{array}{c}-0.12 * * \\
(0.05)\end{array}$ & $\begin{array}{c}0.17 * * * \\
(0.03)\end{array}$ & $\begin{array}{c}-0.28 * * * \\
(0.05)\end{array}$ & $\begin{array}{c}-0.09 * * \\
(0.05)\end{array}$ & $\begin{array}{c}0.14 * * * \\
(0.02)\end{array}$ & $\begin{array}{c}-0.23^{* * *} \\
(0.05)\end{array}$ \\
\hline $\begin{array}{l}\text { One year lagged dependent } \\
\text { variable }\end{array}$ & & & & $\begin{array}{c}-0.34 * * * \\
(0.08)\end{array}$ & $\begin{array}{c}-0.43^{* * *} \\
(0.02)\end{array}$ & $\begin{array}{c}-0.37 * * * \\
(0.07)\end{array}$ \\
\hline Worker characteristics ${ }^{\mathrm{a}}$ & No & No & No & No & No & No \\
\hline Firm characteristics ${ }^{\mathrm{b}}$ & $\begin{array}{c}\text { Dropped } \\
\text { (Time invariant) }\end{array}$ & $\begin{array}{c}\text { Dropped } \\
\text { (Time invariant) }\end{array}$ & $\begin{array}{c}\text { Dropped } \\
\text { (Time invariant) }\end{array}$ & $\begin{array}{c}\text { Dropped } \\
\text { (Time invariant) }\end{array}$ & $\begin{array}{c}\text { Dropped } \\
\text { (Time invariant) }\end{array}$ & $\begin{array}{c}\text { Dropped } \\
\text { (Time invariant) }\end{array}$ \\
\hline Year dummies (7) & Yes & Yes & Yes & Yes & Yes & Yes \\
\hline F statistic & 3.12 & 38.73 & 17.17 & 5.87 & 75.55 & 23.20 \\
\hline R squared & 0.00 & 0.07 & 0.02 & 0.12 & 0.24 & 0.16 \\
\hline Number of observations & 5,459 & 5,459 & 5,459 & 5,459 & 5,459 & 5,459 \\
\hline Number of firms & 1,735 & 1,735 & 1,735 & 1,735 & 1,735 & 1,735 \\
\hline
\end{tabular}

Notes: $* * * / * * *$ significant at the 1,5 and $10 \%$ level. Robust standard errors are reported between brackets.

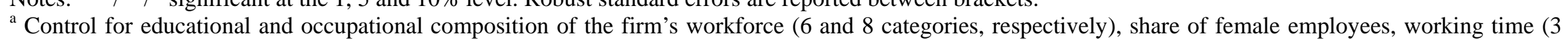
categories) and share of non-standard work contracts.

${ }^{\mathrm{b}}$ Control for firm size (5 dummies), firm vintage age (3 dummies) and industry (8 dummies). 